\title{
"Being stewards of land is our legacy": Exploning the lived experiences of young black farmers
}

\author{
Leslie Touzeau * \\ University of Missouri
}

Submitted July 9, 2018 / Revised September 17 and O ctober 18, 2018 / Accepted O ctober 19, 2018 /

Published online March 10, 2019

Citation: Touzeau, L. (2019). "Being stewards of land is our legacy": Exploring the lived experiences

of young black farmers. Journal of A griculture, F ood Systems, and C ommunity D evelopment, 8(4), 45-60.

https:/ / doi.org/ 10.5304/ jafscd.2019.084.007

Copyright @ 2019 by the Author. Published by the Lyson Center for Civic Agriculture and Food Systems. Open access under CC-BY license.

\begin{abstract}
The oppressive histories of slavery, sharecropping, and discriminatory lending practices contribute to a modern American agricultural landscape where black farmers are underrepresented. While African Americans once made up $14 \%$ of the United States' farmer population, today they only make up $1.4 \%$. Moreover, the American farmer population overall is aging, and currently only $6 \%$ of farmers are under the age of 35. D espite these trends indicating decline, a small population of young black farmers is emerging. This qualitative case study aims to explore the experiences of this previously unexamined group of farmers. Participants found autonomy and self-sufficiency in agriculture, and a particular form of empowerment derived from reclaiming land and actively choosing to engage in work their ancestors were forced to do without

* Leslie Touzeau, D epartment of Rural Sociology; 213 Gentry Hall, University of Missouri; Columbia, Missouri 65211 USA; +1-573-864-0571; letouzeau@gmail.com
\end{abstract}

pay. Findings from the study have implications for agricultural educators, extension professionals, and policy-makers working to cultivate a more diverse and representative body of American farmers.

\section{Keywords}

African American, Agriculture, Black Agrarianism, Black Farmer, Landownership, Y oung Farmer

\section{Introduction}

African Americans have a complicated relationship with American agriculture. For centuries, enslaved African Americans were forced to work the fertile southern soils of the country, often in grueling conditions, for no pay and no promise of even the most basic human rights. After Emancipation, many African Americans continued to work the

\section{Funding Disclosure}

Thank you to Bill Allen and the University of Missouri for funding a trip to the Southeast to visit black farmers. 
land, either as landowners, or, more commonly, as tenant sharecroppers. Even as the slave-like sharecropping system exploited the labor of African Americans, the number of black-operated ${ }^{1}$ farms continued to grow at a staggering rate, with $23 \%$ growth between 1900 and 1920 compared to $10.6 \%$ for white farmers (Wood \& Gilbert, 2000). According to the 1920 U.S. Census, there were approximately 926,000 black farmers that year. After reaching its acme, the number of black farmers began to decline severely. Today, a little over 33,000 black principal operators remain, or $1.4 \%$ of the total U.S. farmer population. ${ }^{2}$

Though the decline of the farmer population is not exclusive to black farmers, their decline has been an exaggerated example of the national trends of the last century. The farming population is an aging and shrinking one, and as farms have consolidated and average farm sizes increased, the individual family farm has become a less viable option for many. Today only $6 \%$ of farmers are under the age of 35, and with two-thirds of U.S. farmland set to transition ownership in the next 20 years, the country stands to lose millions of acres of farm production (Ackoff, Bahrenburg, \& Shute, 2017).

O ver the last century, black farmers have had to tackle a unique set of obstacles that have prevented them from obtaining secure access to land, credit, capital, educational training, and community representation. In 1982, the U.S. Commission on Civil Rights predicted the extinction of black farmers by the year 2000. D espite only making up less than $2 \%$ of the total farming population, black farmers have not disappeared, and since the 2007 Census of Agriculture, there has been a 9\% increase in the number of black principal operators in the United States compared to a $4 \%$ decrease in the number of principal operators of all farms (U.S. D epartment of Agriculture National Agricultural Statistics Service [USD A NASS], 2014b).

There is very little peer-reviewed research on the experiences and challenges of the next generation of young farmers in the United States. The most extensive examinations come from the National Young Farmers Coalition, a nonprofit organization that conducted two surveys, in 2011 and 2017, of farmers age 40 and under. Even rarer are investigations into the unique experiences of the young black farmer, a population that is growing but still frequently overlooked and understudied. The aforementioned quantitative data show a small, but important, increase in the number of young black farmers in recent years, but qualitative data is needed to understand why. Who are these young black farmers, and what motivates them to participate in the agricultural system? What attracts them to farming as an occupation? What are their challenges or barriers to entry? What role, if any, does their race play in any of the above? This exploratory qualitative case study is the first of its kind. Guided by the tenets of black agrarianism, this study aims to investigate the attitudes and motivations of young black farmers and give them an opportunity to share their stories. From this research, four primary themes emerged: (1) black farmers felt a combination of both autonomy and a need for community support; (2) they felt empowered through farming, while recognizing the differences between their experiences and their ancestors'; (3) they engaged in diversified production methods; and (4) they faced minimal overt discrimination but felt a lack of representation on top of the obvious challenges of being a young farmer in the modern agricultural age. I hope that the insights provided here open the door for further research into the lives of young and beginning black farmers so that we may continue to cultivate and encourage diversity in our agricultural occupations.

\section{Review of the Literature}

Much of the research on black farmers in the last century has focused on the problem of their diminishing numbers. Between 1920 and 1997, there was a $98 \%$ decrease in the number of black farmers, compared to an overall decline among white

\footnotetext{
1 "African American" and "black" are used interchangeably in the paper, depending upon the word choice of the cited source or research participant.

2 This Census figure is based on data for "principal farm operator," defined as the person in charge of everyday operations, not necessarily the landowner.
} 
farmers of $66 \%$, which suggests that blackoperated farms decline at a higher rate than whiteoperated farms regardless of their size (Wood \& Gilbert, 2000). The reasons for the falloff are varied and nuanced, and scholars have debated these causes for the better part of a century. Based on the literature, there are several emerging rationales that attempt to explain the incidence of black land loss and the decline in the number of black farmers, including economic hardships as a result of the structural changes in agriculture (Brown, Christy, \& G ebremedhin, 1994; Busch \& Juska, 1997; Lobao \& Meyer, 2001); loss of land through partition sales due to heir property (D yer \& Bailey, 2008; Gilbert, Sharp, \& Sindy Felin, 2002; Pennick, Gray, \& Thomas, 2007; Wood \& G ilbert, 2000; Zabawa, 1991); nonparticipation in govemment programs (Gordon, Barton, \& Adams, 2013; Tyler \& Rivers, 2014); and discrimination at the county, state, and federal levels (Havard, 2001; Hinson \& Robinson, 2008; Pigford v. G lickman, 1999; Wood \& G ilbert, 2000). Additionally, the $G$ reat Migration of the 20th century accounted for the exodus of millions of African Americans from the agricultural South to northern cities where the social and economic opportunities were considered more favorable. Early research indicated that African Americans were fleeing the southern states due to agricultural reorganization and the economic hardships of sharecropping (D rake \& Cayton, 1962; Frazier, 1939). Scholars declare the mid-1970s as the end of the Great Migration period; by 1980, over four million southern-born African Americans lived outside the region (Tolnay, 2003).

\section{L andownership}

Return migration into the South increased after 1970. While many demographic studies at the time were focused on the return migration of southemborn African Americans, a small number of northern-born African Americans were also moving to the South. Falk, Hunt, and Hunt (2004) attribute this migration to three distinct phenomena: (1) political changes in the South that signaled a reckoning with its racist and violent past, (2) familial connection to rural areas where there was potential for landownership, and (3) a cultural understanding of the South as "place." They found that the recent southern return migration had made the African American population less northern and less urban, and they believed this reflected a "call to home" factor that has influenced northern African Americans' decision to return to the land of their ancestors (Falk et al., 2004; Stack, 1996).

For people in rural communities, landownership evokes a certain degree of autonomy and independence (Mooney, 1988; Q uisumbing King, Wood, Gilbert, \& Sinkewicz, 2018). This sentiment holds equally true for African Americans, whose lives and property for so many years were not their own. Research suggests that owning land provides a bevy of economic, social, political, and cultural benefits for African Americans (Balvanz et al., 2011; D yer, Bailey, \& Van Tran, 2009; Hinson \& Robinson, 2008; McCutcheon, 2013; Pennick et al., 2007). In his study of New Deal Resettlement communities, Lester Salamon (1979) found that landownership improved overall community wellbeing and provided social and economic independence. Similarly, Brown et al. (1994) reported that landownership supports rural economies and contributes to feelings of value and self-worth among black farmers. Stack (1996) asserts that the return migration of northern African Americans back to the South is evidence of the importance of landownership as a symbol of stability.

Black farmers and landowners faced decades of discrimination from their local banks, lending agencies, and the U.S. Department of Agriculture (USD A), jeopardizing their ability to retain land and directly threatening their autonomy and livelihoods (D aniel, 2013; Gilbert et al., 2002). A U.S. district court judge recognized these injustices, and in 1999 the Pigford v. G lick man class-action lawsuit allocated approximately US\$1.06 billion to be distributed to black farmers who were affected by these discriminatory practices. Of the almost 23,000 eligible class members, only 15,645 farmers were approved under the Track A process, which provided, among other things, a US $\$ 50,000$ payout per farmer. Another case was subsequently filed to account for black farmers who filed late, and this case, commonly referred to as Pigford II, settled in 2010 for another US\$1.25 billion. (Cowan \& Feder, 2013; Pigford v. G lick man, 1999). 
Bladk A grarianism

The formation of cultural, political, social, and economic values for many rural U.S. citizens stems from a broad agrarian philosophy put forth by Thomas Jefferson in the late $18^{\text {th }}$ century. Jefferson, himself a farmer and slave-owner, promoted a connection between owning property and moral citizenship, with the small family farm representing the ultimate archetype of agrarian ideals. He believed that landownership provided economic independence and the agricultural cultivation of one's land produced strong, industrious citizens and built the foundation for American democracy (Carlisle, 2014; Smith, 2004).

Of course, democratic agrarianism did not apply to African Americans, since they were not, at the time, considered citizens. Instead, there remained a deep-seated yet often overlooked foundational agrarian ideology that underpinned the African American struggle for land acquisition in the United States. Though it shares its roots with the ideals of democratic agrarianism, 'black agrarianism' is something uniquely African American; it has sprung from an opposition to the racist systems of oppression that have permeated rural communities since the first slave was brought to America's shores (Q uisumbing King et al., 2018; Reid, 2012). Indeed, there is a long and proud history of black involvement and production in agriculture in the U.S. (Finney, 2014). In her discussion of black agrarianism, Kimberly Smith (2004) frames her argument within the context of democratic agrarianism but notes that the aftermath of slavery and the constant racial oppression made it difficult for black men to establish a relationship with land and, in many instances, made it impossible to secure property rights. Black agrarians insisted that African Americans had more than earned their right to own land.

Booker T. Washington, the first principal of the Tuskegee Institute in Alabama, was a model black agrarian. Washington's vision of an agricultural future for his people was a pragmatic one. $\mathrm{He}$ believed that economic empowerment and freedom could only come from the skilled cultivation of the land, and it was the duty of educational institutions like Tuskegee to develop these skills in its black students (Smith, 2004). This emphasis on self-reliance and economic prosperity through agriculture still exists in black rural communities today, and this can be observed through all-black agrarian settlements like New Communities in southern G eorgia, black nationalist farms like Muhammad Farms, and the dozens of cooperatives scattered throughout the South that advocate and provide training for black farmers (McCutcheon, 2013; Siby, 2013).

Because black agrarianism is rooted in the collective experiences of slavery, white supremacy, and systematic discrimination, it has developed into an ideology that not only advocates for the virtues of hard work and self-sufficiency, but it is also a form of territorial liberation. Black landownership and an agrarian lifestyle are means to escape the white-dominated system and affirm one's political and civil rights (Q uisumbing King et al., 2018; Reid, 2012). According to Katrina Quisumbing King et al. (2018), black agrarianism is "an emancipatory thrust," and it is related to other projects of social justice, including Black Populism and the civil rights movement. It is through a framework of black agrarianism that we may begin to examine the current state of African Americans in agriculture.

\section{A merica's Y oung Farmers}

The second body of research relevant to this study examines the aging population of U.S. farmers and the lack of young farmers entering the agricultural workforce. The most recent data from the 2012 Census of Agriculture shows that the average age of the American farmer is 58.3 years and that farmers are retiring at a faster rate than new farmers are entering agriculture. In fact, despite the USD A's near decade-long Beginning Farmer and Rancher D evelopment Program, which is aimed at training and assisting new farmers, there were 20\% fewer beginning farmers (farmers who have been farming for 10 years or less) in 2012 than there were in 2007 (USD A NASS, 2014a). While these trends are concerning, the numbers for black farmers are bleaker. Black operators tend to be older than overall operators, with an average age of 61.9 years. Additionally, $42 \%$ of black principal operators are 65 years or older while only $3 \%$ are under the age of 35 , compared with $6 \%$ for all operators 
nationwide (USD A NASS, 2014b).

Recently, a report released by the National Young Farmers Coalition (NYFC) has offered the most thorough information about the state of young farmers in America. Based on its 2017 survey of 3,000 farmers aged 40 years or under, the NYFC found that land access is the number-one challenge for young farmers and the primary barrier to entry. They found that $60 \%$ of young farmers are women, $47 \%$ are farm owners, and $67 \%$ farm on less than 50 acres (20 hectares). Young farmers also tend to be more interested in sustainable practices, with $75 \%$ of respondents choosing to describe their farming practices as "sustainable." Additionally, 17\% of young farmers were certified organic farmers, compared to the national average of just $1 \%$.

0 ther research has reiterated the challenges for young and beginning farmers, recognizing that while acquiring land and capital are the most serious hurdles, developing attachments to the land and making a living from their farms are also difficulties (Inwood, Clark, \& Bean, 2013). Still other literature provides insight into beginning farmer training development and the efficacy of beginner farmer training programs in Virginia (Benson, Niewolny, \& Rudd, 2014; Niewolny \& Lillard, 2010) and assessments of intergenerational values toward landownership (Pennick et al., 2007).

While the dearth of literature on young farmers is stark, studies examining the experiences of young black farmers are virtually non-existent. There has been some investigation into the experiences of young farmers of color in general, most notably from the National Young Farmers Coalition. Its 2017 report found that young farmers are twice as likely to be farmers of color or indigenous than the national average of all farmers. Even so, research shows that black students are more likely to perceive barriers to participating in agricultural careers and hold more negative attitudes toward agriculture and agricultural occupations (Talbert \& Larke, Jr., 1992). Today, the faces of U.S. food producers are neither representative of the diverse U.S. population nor representative of their needs. If black farmers are to persist, and if their voices are to be heard, their numbers must grow and their experiences must be understood. This exploratory study into the lived experiences of young black farmers sheds light on their motivations, characteristics, and challenges, and aims to serve as a starting point for future research.

\section{Methods}

In the spirit of previous qualitative studies on the lived experiences of farmers and attempts by researchers to give a voice to an underrepresented population (Balvanz et al., 2011; Brown \& Larson, 1979; Fiskio, Shammin, \& Scott, 2016), this exploratory qualitative study sought to explore the nature of the new generation of black agrarians and capture their singular experiences through their own voices. This research design benefits from the casestudy approach, which is notable for its in-depth examination of a real-life bounded system, multiple data sources, and an analysis that includes a case description and case themes (Stake, 1995; Y in, 2009). Specifically, I conducted seven semistructured interviews with black farmers in the South and Midwest regions of the U.S. Of those, five were 40 years of age or younger, and they make up the case of young farmers presented in this study. While two farmers fell outside of the bounds of this case, their experiences and observations provided insight into the motivations and challenges of young black farmers. Additional sources of data collected include document analysis and participant observations. The data collection period extended from March 1, 2017, to April 30, 2018.

There is a precedent for this study's sample size in qualitative research examining black farmer populations (Balvanz et al., 2011). Even so, the small sample size and purposive sampling methods associated with this qualitative research do not allow for the development of broad generalizations across this population. The experiences documented by the research are unique to the participant farmers. Despite these limitations, this exploratory study is pertinent and necessary as it introduces a yet unstudied population of young black farmers into the discussion surrounding racial inequities and diverse experiences in agriculture.

Participants

Participants were chosen based on a purposive sampling method. They were recruited at farming 
conferences and pursued through personal farming connections. I spent 10 days researching black farmers in the D eep South (G eorgia, Alabama, and Mississippi), and during this time I was able to interview and record numerous on-farm observations of both study participants and other knowledgeable individuals within the black farming community. Five self-identified black farmers 40 years of age or younger who farm in the Southern or Midwestern states participated in this study (see Table 1), and these criteria formed the basis of the bounded system. ${ }^{3}$ Among the participants, three were male, two were female, and all five had at least some college-level education. Two were landowners farming on family land, while the other three planned to begin their search for land to purchase within the next few years.

$D$ ata Collection

I contacted the participants individually, on separate occasions, and met each in person at an agreed-upon location. Before our interview, they were briefed on the project and its objectives, informed of the confidentiality information, and provided with a copy of the IRB consent form and researcher contact information. The same general guiding questions and interview protocol were used for all participants, but due to the semistructured nature of the interviews, questions were altered or added as needed based on the direction of the conversation. In general, participants were interviewed on their background in agriculture, their attraction to farming, the challenges they have faced, the importance of African American involvement in agriculture, and their advice for new black farmers. Interviews lasted from 45 to 90 minutes, and they were audio-recorded and transcribed. All identifying information was removed during the transcription, and pseudonyms were assigned to each participant.

$D$ ata $A$ nalysis

Initial interview audio was transcribed by hand, coded line-by-line, and together with observation notes and document analyses, an initial set of codes was inductively developed. These codes guided subsequent interview data, and additional codes were added as necessary. In total, the preliminary codebook comprised 51 codes. Content analysis revealed several patterns. Through an iterative

Table 1. Demographics of Participant Farmers

\begin{tabular}{|c|c|c|c|c|c|}
\hline & Robert & Ashley & Malik & Antwon & Rose \\
\hline Age & 26 & 28 & 39 & 40 & 29 \\
\hline Sex & Male & Female & Male & Male & Female \\
\hline Region & South & Midwest & Midwest & South & South \\
\hline Education & B.S., Agriculture & B.A., Architecture & Some college & Some college & B.A., Anthropology \\
\hline Years Farming & 3 & 1 & 1 & 15 & 5 \\
\hline Farming Employment & Full-time & Part-time & Full-time & Full-time & Full-time \\
\hline Production Type & Produce, pecans & Produce & $\begin{array}{l}\text { Milo, wheat, } \\
\text { livestock }\end{array}$ & $\begin{array}{l}\text { Produce, livestock, } \\
\text { dairy, row crops }\end{array}$ & $\begin{array}{l}\text { Produce, medicinal } \\
\text { herbs }\end{array}$ \\
\hline Farming Practices & $\begin{array}{l}\text { Non-organic and } \\
\text { certified organic }\end{array}$ & $\begin{array}{l}\text { Organic methods } \\
\text { (not certified), } \\
\text { permaculture }\end{array}$ & $\begin{array}{l}\text { Non-organic, } \\
\text { sustainable } \\
\text { practices }\end{array}$ & Non-organic & $\begin{array}{l}\text { Organic methods } \\
\text { (not certified) }\end{array}$ \\
\hline Acreage & 1636 & 5 & 700 & 150 & 2 \\
\hline Generation in Farming & $3^{\text {rd }}$ & $1^{\text {st }}$ & $3^{\text {rd }}$ & $4^{\text {th }}$ & $1^{\text {st }}$ \\
\hline Current Employment & $\begin{array}{l}\text { Farmer at } \\
\text { nonprofit }\end{array}$ & Architect; farmer & Farmer & Farmer & Farmer at nonprofit \\
\hline Landowner? & No & No & Yes & Yes & No \\
\hline
\end{tabular}

3 The National Y oung Farmers Coalition's 2017 survey of young farmers used age 40 as the cut-off to define a young farmer. 
process of reviewing transcripts and utilizing code frequency counts, 13 categories emerged from the data, and these categories were grouped into four overarching themes (Patton, 2002; Stake, 1995; Y in, 2003). The four themes identified in this study are discussed in the findings section along with representative quotes from the five participants.

Multiple methods were used to establish the overall trustworthiness of this study (Creswell, 2013). The data were triangulated using analyses from documents, information from the literature, participant observations, member checks, and informal discussions with other black farmers. Both the data and the analysis procedures underwent peer debriefing. D espite a small sample case, my intention is for this exploratory study to lead to further research on the subject and the development of future transferability.

\section{Statement of Positionality}

The researcher is the primary instrument in qualitative inquiry, and therefore it is necessary for qualitative researchers to disclose their positionality and potential biases (Creswell, 2013). I am a young black farmer myself, and as such have an obvious personal bias regarding the subject matter and a vested interest in the well-being and success of my fellow young black farmers. Although this personal investment may put me at risk of imparting verification bias on the study and simply using this inquiry to confirm my preconceived beliefs, my identity as a member of this small community granted me unique insights into the lives of the participants. I was the sole interviewer of all participants, and I conducted exclusively in-person interviews to connect with the participants at a more personal level than phone interviews would allow. I remained cognizant of my position within the research throughout the project by keeping memos after each interview and writing reflexive journal entries. I worked to bracket out my own perceptions and to reflect on how my experiences as a young black farmer were similar and different from those of the participants.

\section{Results}

Following a thorough analysis of the data, four themes emerged: (1) Concurrence of Autonomy and Community Support; (2) From Struggle to Empowerment; (3) Innovative, D iversified Production; and (4) The Emerging Face of Y oung Black Farmers. Discussions of various categories within each theme as well as relevant quotes from participants are presented below.

C oncurrence of A utonomy and C ommunity Support Throughout our discussions, an intriguing paradox emerged between the farmers' desire for independence and their need for connection to a community and a support system. When asked what they loved about being a farmer, four of the five participants identified the ability to be one's own boss as a primary benefit to farming. Even Robert, who worked for a nonprofit farm and consequently had a boss, found freedom in the farm life, stating, "pretty much, you're your own boss. You wake up every morning, you make your own schedule. ... O ut here, being a farmer, it's more freedom; you make your own decisions." This notion of the importance of autonomy was often reiterated. For Malik, farming was not just a job; it was a lifestyle that he was proud of and found more worthwhile than working a job with the sole goal of making ends meet:

Working for the man, it's like, there was no purpose. It was just to make sure my bills were paid, keep a roof over my head, and do the same thing the next day, you know? I have the opportunity to do something, so I have to take advantage of it. ... what's it say? With great power comes great responsibility?

In Antwon's view, farming was a way to fulfill his entrepreneurial goals and provide for his family without having to report to anyone or split his pay with anyone. For him, the benefits were obvious: why would he want to make money for someone else when he can make it for himself?

You know, we can make our own money individually and they out here working 8-12 hours for a factory, and you go do 10-12 hours on the farm and make just as much money, less of a headache, and you're your own boss. 
Autonomy and the freedom from working for others were motivations for these participant farmers, but if autonomy is the freedom to determine one's actions, then self-sufficiency goes one step further and allows for the provision of one's resources without dependence on others. To Robert, self-sufficiency on the farm meant being able to learn a wide variety of skills and take care of problems as they arose without the need to spend money on off-farm assistance. At the farm he worked on, a five-person crew was in charge of managing all aspects of the farm, including tractor maintenance and care. With a bit of pride, Robert said, "I came into it as a farmer, but I'm leaving as a mechanic, a carpenter, everything. It's hard work, but a lot of the stuff we do here is on our own, learning, which is good."

Ashley differentiated between the importance of autonomy and self-sufficiency, stating "even if you have autonomy, you can do whatever you want... that's great and all, but you know, what happens if you need food and there's no grocery store anymore?" While autonomy may logically serve as a prerequisite for self-sufficiency, Ashley framed self-sufficiency as an empowering state of personal caretaking. She emphasized that growing her own food was taking care of herself, and said, "if we forget how to take care of ourselves, we're then dependent on someone else who may or may not know how to take care of us." She had a general distrust of those who would attempt to misinform or take advantage of her and saw dire consequences in not being adequately skilled in growing food, "because if everything goes to shit, or if everything kind of falls apart, am I really able to restart?"

Rose, a vegetarian, started farming as a way to increase her access to fresh fruits and vegetables and to be an example of self-sufficiency for her children. She saw farming and gardening as tools for educating her community about taking back control of their health and their bodies. She added, "I think as African American people, it's really important for us to have agency over our food and our food system because if you don't have control over your food, people can control your whole life, I think."

Even as all participants espoused the virtues of autonomy and self-sufficiency and cited them as motivations for their farming careers, they by no means desired isolation. Participants emphasized the importance of having experienced mentors, a support system composed of other black farmers, and a strong connection to community. Antwon remarked that having other people on the farm was key, as farming is not something one can do alone. For Malik, creating friendships with his neighbors was the best way to learn about different practices he was interested in adding to his farm, like cover cropping and buffalo production.

Rose worked and lived in an urban community, and the black support system she had amassed was very important to her, especially in a field dominated by white men. She said:

I think I'm lucky that there is a really strong network of black people who are doing work around food access. I feel like I'm very supported and have a very strong community. I don't even really have to interact with white people. [laughs]

On the other hand, A shley lived in a predominantly white area of her state, and she struggled with the lack of a black community nearby. She emphasized the importance of having other African Americans around her, saying, "When you are black and identify as black, and then you learn what it means to be black, it becomes increasingly important to be connected with people that get it, and that can feel you, you know?"

Finally, participants felt their roles as farmers also gave them the opportunity to give back to members of their community. Ashley acknowledged the difficulties black people have faced over the centuries and saw her role in the community as an educator, stating:

I think providing the tools and the knowledge and sharing the information that's necessary so that people can be self-empowered to take care of themselves is paramount. That's more important to me than just growing something and providing that to them. I think knowledge is the greatest power and tool that we can share with each other ... the key to the gates 
of liberation is knowing what to do and how to do it.

\section{From Struggle to E mpowerment}

Centuries of slavery, racism, and exploitation forced many African Americans into an agrarian life for the benefit of American agriculture. Subsequently, many were pushed off of the land and left the South to start more viable and lucrative lives in cities across the country. Rose saw a marked lack of African Americans in agriculture and attributed this to two things:

I really think it's because of our history of being systematically discriminated against and pushed off of our land. And then, also, the negative ideas we have around agriculture. ... I think there's some shame in it because of being enslaved.

For these participants, a recurring theme was a discernable transition from viewing farming as oppressive and representative of struggle to a worthwhile and fulfilling career. Unlike their ancestors, these participant farmers made an active choice to pursue farming, and they were all pleased with their choice. Participants saw farming as a joy, an occupation that they loved and would not have traded for anything else. Robert joked about getting to have a truck as one of the perks of being a farmer, while Antwon summed up his feelings this way:

I can't name one thing I D O N'T love about being a farmer. I love it all. Just, the outdoors, the weather, the environment, the peace, the rush, the growth, the struggles, the successes. It's not a dull moment. Every day is different. I mean, really every day, every MOMENT is different on the farm.

Rose echoed a similar sentiment, stating:

Um, I just love plants! I love them. I think they're amazing and I think that they are really healing. Working with the land is really healing and it's energizing, and it's fun, and I love educating people, I love eating the food, seeing people eat the food.... I just, I love everything about it.

For Malik, his chosen path was dictated by his spirituality, and he felt called to do the work he was doing: "I'm really just glad to be able to do it. O bviously, this is what the Lord wanted me to do, so I'm glad I'm getting that opportunity to do it. And I just hope I do it well."

Beneath the overarching theme of empowerment emerged a specific connection to agriculture by way of African or African American ancestors. Ashley did not grow up on a farm, and she admitted that she had little experience with farming or gardening. She remembered her grandmother's garden patch behind her house, although gardening was "never a thing that [my grandmother and I] did together." Even so, she described being involved in agriculture as something that just felt right:

There's some things that just kind of click, you know. ... It's just like, you start doing something and it's just like, oh yeah! It's like remembering. And so ... it's like a segue or conduit to kind of remembering who we once were as a people.

Rose recognized a deep detachment from the land within her black community and she believed that reconnecting to agriculture meant reconnecting with her cultural heritage and her ancestors, saying, "I think there is a lot of pain that we have associated with the land and that by reconnecting with it that we can really heal a lot of that generational trauma that we have." In Malik's family, farming and landownership have always been points of pride, and his family was successful in their endeavors. He returned to the family farm to take it over because he felt it was his duty, saying, "It's just too many years of blood, sweat, and tears that's gone into that farm for me to just let it go. No one else can do it, I mean, I'm the only one left."

This concept of a natural inclination toward agriculture was expressed throughout many of my discussions with participants. Antwon saw farming as something "that has been in our African American bloodline since ... day one I guess you could 
say." Robert saw himself as an extension of his family, all of whom worked on farms when he was younger. Because he spent his life around farms, he was drawn to the work, saying "I knew that I had it in me, you know, as far as how to grow, when to grow." It seems he not only had a familial connection to agriculture, but also a deeper-seated, ancestral connection that he believed was just a part of who he is. He spoke of a conversation he had with a student:

Back in the day of slavery, black people did all the work to the land and the master, you probably ask him a question he wouldn't be able to tell you. I said, the world ain't changed. I said, now in this age, we should be owning farms, owning land, but people don't know that the people that actually farm the best are the people that did it back in the day. You know, so I was saying, it kind of comes naturally to me, you know, because I feel like it was already in my blood. Past family already did it, and they knew how to do it, so it's like you born with that, that, that good gene, you know?

For these farmers, what was once a source of hardship and oppression became a symbol of empowerment in which they were able to learn skills of self-sufficiency, develop a work ethic, and escape the control of society over their livelihoods. More than that, though, farming had emancipatory value as both a connection to an ancestral past and as a reclamation of what was once a forced burden. Ashley summed this up well, saying,

Because you're not a slave, that's EXACTLY why you should farm. Because, I mean, take care of yourself. Like, because you can, because you are not chained up. Y ou have access to whatever knowledge and information you want to have.

Innovative, D iversified Production Every farmer participating in the study was engaged in some form of diversified production, in contrast to much of the American agricultural landscape today. Malik operated 700 acres (283 hectares), which were made up of a mix of milo, wheat, and livestock pastureland. Rose worked for an urban nonprofit farm where she grew a variety of produce and medicinal herbs. Ashley's farm was new and unplanted at the time of the study, but her plans included planting an orchard and using permaculture design to grow perennial vegetables. Antwon managed the diverse operations of his family farm: he ran beef cattle, raised hogs, grew produce, and operated a dairy, all on his 150-acre (61-ha) farm. Finally, Robert oversaw a 1,636-acre (662-ha) former plantation turned nonprofit that had invested in everything from a 200-acre (81-ha) pecan grove to certified organic vegetable and wine grape production.

All participants also underscored the importance of working outside the bounds of traditional agriculture to set themselves apart from competitors, utilizing innovative marketing strategies and production methods. For some of the farmers, these tactics stemmed from a sense of ecological responsibility and land stewardship. Malik had recently learned a new technique to apply to his farm, saying:

I've been talking to these people about the cover crops. And I'm like, why doesn't everyone jump on this? I mean, it's so ... it makes so much sense. It's like, you're protecting the land, you're keeping weeds out, and you're making nutrients, and all that and moisture stay in there, so why wouldn't people do that? I don't see a lot of that being done where I'm at. So ... yeah, I'm ready to think outside the box. G ot to these days.

Ashley imagined her farm as a space of mutual care, where her sustainable practices nourished the land and the land in return revitalized her:

I love connecting with the bees and butterflies and developing a whole new relationship with nature and all of its little components. I mean, that was a really powerful experience that I've had working on a farm, is ... understanding the different types of relationships that we can have with non-human creatures. 
For other participants, diversification and innovation were essential to the financial viability of their operations. Antwon and his family were tobacco farmers for several generations until recently, when it became no longer profitable. Antwon then directed his energies toward coming up with new ways to sell his products. At the time of the study, he had just started a door-to-door produce delivery service and had begun to create some value-added items from his meat and produce. He said:

We always have these unique ideas and ways to set ourselves different from everybody else's product or whatever ... We started selling pork chops, brats, and value-added meats that we had on the farm. And four to five months after that, everybody at the market started selling pork chops, brats, same thing we selling. And then we would see them peeking around comers, looking at our prices, trying to be competitive and everything.

Robert's feelings on land stewardship and sustainability emerged as he talked extensively about the organic and sustainable practices of the large farm where he worked and the farm he worked on in college. For him, organic production was important for several reasons, including eating healthy, battling obesity in America, and capitalizing on an expanding organic market, stating, "I know organic is going to blow up real soon, so if I can get the jump on it.... " He asserted that conventional sprays for vegetables could be harmful and unhealthy, and, as a farmer, he wanted to educate people on their food choices, saying, "It starts in the ground. What is spread on the grass that the cows eat. What are you feeding the cow, you know? If you know all these things, you'll look at the way you eat a little different." He also saw being organic as a way to connect and interact positively with his plants and the land. He said, "If you're a farmer and you don't have a relationship with your plants, organic is not for you. If you can't walk out there and like seeing your stuff grow, organic is not for you."
The F ace of $\mathrm{Y}$ oung Bladk Farmers

All participants had much to say on the topic of the next generation of black farmers. Many of them recognized the obvious shortage of other black farmers, especially farmers under 40 , in their communities. A shley and I were able to commiserate about the absence of black farmers in the Midwest. When talking with me about other black farmers she knew, she said, "Um, you're probably the first person, even though we were not farming together. When I saw you [at our friend's farm], I was like, oh, there's a black person!"

Robert attributed the shortage of black farmers to the childhood memories of hard work growing up on a farm and the desire to pursue another profession, saying:

G rowing up ... you working in the field as a child, and it's tiring, you know? I don't wanna be out here, I'm sweating. Y our hands are picking cucumbers, and picking okra, you don't know why you itching that much. ... G rowing up having to do that, [young people] get older and as soon as they get a chance to go out, they do.

Robert admitted that his own father and grandfather did not like farming and did not want anything to do with it. Today, he said, "everywhere I go, I'm the youngest. If somebody's farming, either the dad owns the farm or it's in the family... I haven't seen a black farmer younger than 35 actually." In Antwon's opinion, there were few young black farmers because agricultural programs like 4-H and FFA were predominantly white and were not working to attract people of color, much like his own experience in high school. Additionally, he thought young people did not consider agriculture to be a lucrative career. Giving an example of his own childhood growing up on a farm, he said, "We never saw the money flow, the cash flow, never saw the income. We always heard about bills, bills. We never seen fun times."

While the overall decline of the black farmer population in the $20^{\text {th }}$ century has been attributed to discrimination and racism, these young farmers, unlike previous generations, did not believe they face racial discrimination on par with their 
predecessors. Instead, they believed their status as young farmers was the determining factor of their respective barriers to entry. Much like their white peers, they cited issues like land access, access to capital, and financial constraints as their primary challenges. For Malik, it was debt that was holding him back:

I can't think about anything but this debt. I mean, let's just be real. Y ou know, it's hard for me to really focus on anything but that, but I think once that is finally taken care of to a point where we can take a breath again, I think it'll be better, and I'll be able to be a little more comfortable with what I'm doing.

Ashley thought access to land and capital were the biggest barriers for young farmers, and Rose reiterated this, saying, "Land access. Y ou know, that's something that, I think a lot of people are struggling with right now. It feels very daunting."

Robert, who farmed in the D eep South, said, "I haven't seen any real challenges as far as discrimination and all that. ... I mean, you get looks ... [but that's] people just not understanding why you are in this business. For me, being young, I don't really face any challenges." Antwon, also a southern farmer, felt similarly about his experiences:

It seems like the dairy community family is a totally different family. All they worrying about is making sure their family survive, if we all gonna make money. Y ou know, race doesn't play an issue with them. I mean it's never even brought up really. You know, you walk in and they start talking to you, the main thing they wanna know is if you a dairy farmer. Once you say yeah, you already got the bond.

Malik noticed subtle looks from people but did not believe he had dealt with any racial discrimination in his community. He said,

I haven't really experienced anything based on, you know, really just based on my race. I mean, you got the old white ladies once in a while wanna give you a side-eye, but other than that, I mean, I don't really have to deal with that.

In Ashley's experience, her interactions with the white farming community had been mostly positive. The farmers she knew were small-scale, diversified in their production, and, as she described them, white but open-minded and liberal. She did mention feeling unwelcome at times within her rural community, and when asked to describe what she meant, she said:

It's always very subtle. A good example which has happened many a time, not necessarily in farming, but it does kind of typify the instances where I don't feel welcome, is not being acknowledged, not being looked at as a part of a group. ... It's like, I'm not invisible, right?

This lack of black representation within the farming community was a common thread among the participants. Antwon, who served on the board of the D airy Farmers of America, said that he had to make comments to other board members about the lack of diversity in their advertising, saying "every time you show a commercial, you don't show the true color of agriculture. If you don't show that, then our youth will never know." For Robert, his principal concern with white peers was an inability to effectively communicate with them because he was not one of them. He said,

The challenge is the lack of knowledge that I can get from other farmers. The disadvantage to me is, they don't have that conversation with me like they would with other people. So, I have to put myself in places and predicaments where I know I'm not comfortable in, just to get a lick of knowledge or something.

Rose attended a farming conference and noticed right away the lack of people of color. She believed that farmers of color must create a space for themselves and come together to network and talk about their work. She explained her disgruntlement this way: 
It is very disheartening when it feels like the things that impact us as people of color are not on the larger stage and we don't necessarily have representation. And so that's what I think impacts me the most is really just wanting to see more people like me or like us doing this work and hearing about their stories and, yeah. Just knowing that we have a platform and an opportunity.

Nevertheless, she was optimistic. She said:

[There is] a new generation of young black people who are recognizing that it's important for us to have this profession and are trying to get back to it, I think. ... There is an open space that I think we can really take advantage of right now and be leaders within it because it feels like more and more people are valuing what we have to say and our stories and are seeing more of the benefits of letting people of color have agency over their own community and over the work within their own communities.

\section{Discussion}

This research makes an important contribution to the study of black agrarianism in that it is among the first to examine a young black farmer population. As a qualitative case study, these findings are limited to this specific bounded case and the participants therein. However, transferable lessons can be drawn that apply to broader populations of young farmers of color. Many of the findings were consistent with those found in previous research about black farmers. Much like the older generations, these young black farmers tended to farm on smaller parcels of land and engage in more diversified production compared to their white peers (Brown \& Larson, 1979; Pennick et al., 2007; USD A NASS, 2014b). Landownership as a source of power and self-sufficiency emerged as a theme from this study, which is consistent with previous literature (D yer et al., 2009; Hinson \& Robinson, 2008; Quisumbing King et al., 2018). Notions of connection to land, independence, and selfsufficiency as food-producing citizens track with ideals held by black agrarians. As black agrarianism suggests, these participants farmed in order to care for the land, provide knowledge and resources to their communities, and maintain resilient links between their people, their history, and place (Q uisumbing King et al., 2018; Smith, 2004). Interestingly, this theme emerged even in conversations with participants who did not yet own their own land but hoped to soon, indicating the pervasiveness of the notion that land equals power in the black community. The paradox between autonomy and community support is telling of a population of farmers who both value their autonomy-as a way to protect themselves from the dependence on an American society that once deemed them subhuman - and a desire for social cohesion through a supportive and informative community. D espite the general consistency between this research and prior black agrarianism research, the findings from this study diverged from black agrarianism's political and activist emphasis. Participants were motivated to take care of themselves, their families, and their communities, but they did not necessarily see their involvement in agriculture as an explicitly political act.

Perhaps the most marked diversion from previous scholarship on black farmer populations was the lack of explicit discrimination, racism, or oppression experienced by participants (Balvanz et al., 2011; D aniel, 2013; G ilbert et al., 2002). Though we certainly cannot extrapolate to say that racism and discrimination against African Americans is no longer a problem in agriculture, it is noteworthy that these concerns were not at the forefront of the minds of these young black farmers. It is easy to observe the racism in agriculture through instances like the Pigford case, but that search for explicit racism obscures the underlying concerns of these young black farmers. Just because these farmers felt that they had not faced explicit discrimination does not mean that they did not face other barriers or feel uncomfortable in agricultural spaces. While their ancestors may have been denied loans from the USD A or faced other overt forms of oppression, these participants were living in the era of micro-aggressions, in which their race-based concerns centered on more subtle issues such as a lack of representation in the agriculture industry or encounters with implicit bias. In 
terms of barriers to success in agriculture, participants' worries were not racially focused, but reminiscent of the concerns of young farmers across the country (Ackoff et al., 2017; Benson et al., 2014). Participants worried about debt, about being able to afford and acquire land, and about gaining access to the training and resources they needed to be successful. They did not believe their race was a barrier, beyond simply making them a bit of an anomaly in their agricultural communities, but they did believe that factors such as being young or not being born into farm families were hindrances to their ability to be successful in agriculture.

\section{Conclusion}

By proposing themes that serve as a framework for understanding the lives of young black farmers, this exploratory case study serves as the basis for future research into this understudied population. Although the participants engaged in varying types of agriculture, brought diverse backgrounds to the study, and expressed unique motivations as farmers, they were unified by a shared commitment to self-sufficiency and autonomy, benefited from the support of their community, and felt empowered by the prospect of owning land and feeding themselves.

The shadows of slavery and discrimination hang over American agriculture, yet the experiences of these participants demonstrate that there is more to the story of the modern black farmer. Agricultural educators, extension professionals, policy-makers, and researchers alike must consider the emancipatory elements of agriculture when working with or recruiting young African Ameri- cans into agriculture. If we are to continue to build new and refine current programs aimed at recruiting a more diverse group of people, and particularly young people, into the agricultural field, we must understand their motivations, needs, and challenges in order to properly tailor assistance.

Further research into the experiences of young black farmers is needed and warranted. All participants in this study farmed on diversified operations, so future studies may benefit from the inclusion of agricultural perspectives that represent more conventional systems of agriculture. Additional research could include a mixed-methods approach that integrates quantitative survey data on the diverse population young farmers to create a more comprehensive picture of their challenges and motivations. As researchers and practitioners work toward creating a just and equitable food system that is as diverse as the country's population, studies like this one are invaluable. The face of agriculture in this country is changing, and we must be equipped with the tools to support and recruit new farmers, including understanding their potential motivations and hardships.

\section{Acknowledgments}

I would like to thank a number of people whose guidance, support, and assistance made this research possible. Thank you to my graduate committee, Dr. Mary Hendrickson, Dr. Anna Ball, and Dr. Hua Q in, for your advice and tutelage. Thank you to my participants for taking the time to talk with me and for being open and honest about your experiences. Finally, thank you to Dr. Sarah Cramer for your infinite wisdom and assistance with the manuscript.

\section{References}

Ackoff, S., Bahrenburg, A., \& Shute, L. L. (2017). Building a future with farmers II: Results and reommendations from the N ational Y oung F armer survey. Hudson, NY : National Y oung Farmers Coalition. Retrieved from https:// www.farmlandinfo.org/ building-future-farmers-ii-results-and-recommendations-national-young-farmersurvey

Balvanz, P., Barlow, M. L., Lewis, L. M., Samuel, K., O wens, W., Parker, D. L., De Marco, M., Crowder, R., Williams, Y., Barker, D ., Lightfoot, A., \& Ammerman, A. (2011). "The next generation, that's why we continue to do what we do": African American farmers speak about experiences with land ownership and loss in North Carolina. Journal of A griculture, F ood Systems, and Community D evelopment, 1(3), 67-88. https:/ / doi.org/ 10.5304/ jafscd.2011.013.011

Benson, M. C., Niewolny, K., \& Rudd, R. D . (2014). A n evaluation of program, training, and resource needs of V irginia beginning farmers and ranchers: V irginia Beginning Farmer and Rancher Coalition Program. Blacksburg: Virginia Tech. http:/ / hdl.handle.net/ 10919/56050 
Journal of Agriculture, Food Systems, and Community Development

ISSN: 2152-0801 online

https:/ / www.foodsystemsjournal.org

Brown, A., Jr., Christy, R. D ., \& G ebremedhin, T. G . (1994). Structural changes in U.S. agriculture: Implications for African American farmers. The Review of Bladk Political E conomy, 22(4), 51-71. https:/ / doi.org/ 10.1007/ BF02689979

Brown, M. M., \& Larson, O. F. (1979). Successful Black farmers: Factors in their achievement. Rural Sociology, 44(1), 153-175.

Busch, L., \& Juska, A. (1997). Beyond political economy: Actor networks and the globalization of agriculture. Review of International Political E conomy, 4(4), 688-708. https:/ / doi.org/ 10.1080/ 09672299708565788

Carlisle, L. (2014). Critical agrarianism. Renewable A griaulture and Food Systems, 29(2), 135-145. https:/ / doi.org/ 10.1017/ S1742170512000427

Cowan, T., \& Feder, J. (2013). The Pigford cases: USD A settlement of discrimination suits by black farmers (Congressional Research Service Report No. RS20430). Retrieved from http:/ / nationalaglawcenter.org/ wp-content/ uploads/ assets/ crs/ RS20430.pdf

Creswell, J. W. (2013). Q ualitative inquiry \& research design: C hoosing among five approaches. Thousand O aks, CA: Sage Publications.

Daniel, P. (2013). D ispossession: D iscrimination against A frican A merican farmers in the age of Civil Rights. Chapel Hill: University of North Carolina Press.

Drake, S. C., \& Cayton, H. R. (1962). Bladk metropolis: A study of negro life in a northern city. New Y ork: Harper \& Row.

Dyer, J. F., \& Bailey, C. (2008). A place to call home: Cultural understandings of heir property among rural African Americans. Rural Sociology, 73(3), 317-338. Retrieved from https:// onlinelibrary.wiley.com/ journal/ 15490831

Dyer, J. F., Bailey, C., \& Van Tran, N. (2009). O wnership characteristics of heir property in a Black Belt county: A quantitative approach. Southern Rural Sociology, 24(2), 192-217. http:/ / journalofruralsocialsciences.org/ index.htm

Falk, W. W., Hunt, L. L., \& Hunt, M. O . (2004). Return migrations of African-Americans to the South: Reclaiming a land of promise, going home, or both? Rural Sociology, 69(4), 490-509. Retrieved from https:// onlinelibrary.wiley.com/ journal/ 15490831

Finney, C. (2014). Black faos W hite spaøs: Reimagining the relationship of A frican A mericans to the great outdoors. Chapel Hill: University of North Carolina Press. https:/ / doi.org/ 10.5149/ northcarolina/ 9781469614489.001 .0001

Fiskio, J., Shammin, M. R., \& Scott, V. (2016). Cultivating community: Black agrarianism in Cleveland, O hio. G astronomica: The Journal of C ritical Food Studies, 16(2), 18-30. https:/ / doi.org/ 10.1525/ gfc.2016.16.2.18

Frazier, F. E. (1939). The negro family in the U nited States. Chicago: University of Chicago Press.

Gilbert, J., Sharp, G., \& Sindy Felin, M. S. (2002). The loss and persistence of black-owned farms and farmland: A review of the research literature and its implications. Southern Rural Sociology, 18(2), 1-30. http:/ / journalofruralsocialsciences.org/

Gordon, J. S., Barton, A., \& Adams, K. (2013). An exploration of African American forest landowners in Mississippi. Rural Sociology, 78(4), 473-497. https:/ / doi.org/ 10.1111/ ruso.12014

Havard, C. J. (2001). African-A merican farmers and fair lending: Racializing rural economic space. Stanford L aw \& Policy Review, 12(2), 333-360. https:/ / law.stanford.edu/ stanford-law-policy-review-slpr/

Hinson, W. R., \& Robinson, E. (2008). "We didn't get nothing”: The plight of black farmers. Journal of A frican A merican Studies, 12(3), 283-302. https:/ / doi.org/ 10.1007/ s12111-008-9046-5

Inwood, S., Clark, J. K., \& Bean, M. (2013). The D iffering Values of Multigeneration and First-Generation Farmers: Their Influence on the Structure of Agriculture at the Rural-Urban Interface. Rural Sociology, 78(3), 346-370. https:// doi.org/ 10.1111/ ruso.12012

Lobao, L., \& Meyer, K. (2001). The great agricultural transition: Crisis, change, and social consequences of twentieth century US farming. A nnual Review of Sociology, 27, 103-124. https:/ / doi.org/ 10.1146/ annurev.soc.27.1.103

McCutcheon, P. (2013). "Returning home to our rightful place": The Nation of Islam and Muhammad Farms. G eoforum, 49, 61- 70. https:/ / doi.org/ 10.1016/ j.geoforum.2013.05.001

Mooney, P. H. (1988). My own boss? Rationality and the family farm. Boulder, CO: Westview Press.

Niewolny, K. L., \& Lillard, P. T. (2010). Expanding the boundaries of beginning farmer training and program development: A review of contemporary initiatives to cultivate a new generation of American farmers. Journal of A griculture, Food Systems, and Community D evelopment, 1(1), 65- 88. https:// doi.org/ 10.5304/ jafscd.2010.011.010 
Patton, M. Q. (2002). Q ualitative research and evaluation methods (3rd Ed.). Thousand O aks, CA: Sage Publications.

Pennick, E., G ray, H., \& Thomas, M. N. (2007). Preserving African American rural property: An assessment of intergenerational values toward land. In J. L. Jordan, E. Pennick, W. A. Hill, \& R. Zabawa (Eds.), L and and Power: Sustainable A griculture and A frican A mericans (pp. 153-173). Sustainable Agriculture Research and Education (SARE) Program.

Pigford v. G lickman. (1999). 185 F.R.D. 82; 1999 U.S.D ist.LEXIS 5220.

Q uisumbing King, K., Wood, S. D ., Gilbert, J., \& Sinkewicz, M. (2018). Black agrarianism: The significance of African American landownership in the Rural South. Rural Sociology, 83(3), 677-699. https:/ / doi.org/ 10.1111/ ruso.12208

Reid, D . A. (2012). Introduction. In D . A. Reid \& E. P. Bennett (Eds.), Beyond forty acres and a mule: A frican A merican landowning families sinœ Reconstruction (pp. 1-18). Gainsville: University Press of Florida. https:// doi.org/ 10.5744/ florida/ 9780813039862.003 .0001

Salamon, L. M. (1979). The future of black land in the South. In L. McG ee \& R. Boone (Eds.), The Bladk rural landowner - endangered species: Social, political, and economic implications (pp. 155-196). Westport, CT: G reenwood Press.

Siby, R. (2013). Social equity in public administration: The work of the F ederation of Southern Cooperatives/ L and A ssistanœ F und. Kennesaw State University.

Smith, K. K. (2004). Black agrarianism and the foundations of black environmental thought. E nvironmental E thics, 26, 267-286. https:/ / doi.org/ 10.5840/ enviroethics200426316

Stack, C. B. (1996). Call to home: A frican A mericans reclaim the rural South. Basic Books.

Stake, R. E. (1995). The art of case study research. Thousand O aks, CA: Sage Publications.

Talbert, B. A., \& Larke, Jr., A. (1992). A ttitudes toward agriculture of minority and non-minority students enrolled in an introductory agriscience course in T ex as (Texas A\&M University Bulletin 92-1). College Station: Texas A\&M University.

Tolnay, S. E. (2003). The African American "G reat Migration" and beyond. A nnual Review of Sociology, 29, 209-232. https:// doi.org/ 10.1146/ annurev.soc.29.010202.100009

Tyler, S. S., \& Rivers, Louie, I. (2014). Michigan black farm owners' perceptions about farm ownership credit acquisition: A critical race analysis. Raœ, $\mathrm{G}$ ender, and Class, 21.3(4), 232-251.

U.S. D epartment of Agriculture National Agricultural Statistics Service [USD A NASS]. (2014a). U .S. C ensus of A griculture 2012 H ighlights: Beginning Farmers A CH 12-5. Washington, D .C.

USD A NASS. (2014b). U.S. C ensus of A griaulture 2012 H ighlights: Bladk F armers A C H 12-10. Washington, D .C.

Wood, S., \& Gilbert, J. (2000, Spring). Returning African-American farmers to the land: Recent trends and a policy rationale. The Review of Black Political E conomy, 27, 43-64. https:/ / doi.org/ 10.1007/ BF02717262

Y in, R. K. (2003). C ase study research: D esign and methods. Thousand O aks, CA: Sage Publications.

Zabawa, R. (1991). The Black farmer and land in south-central Alabama: Strategies to preserve a scarce resource. H uman E ology, 19(1), 61-81. https:// doi.org/ 10.1007/ BF00888977 